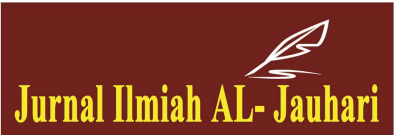

Jurnal Ilmiah AL-Jauhari: Jurnal Studi Islam dan Interdisipliner

Volume 5 No 1 (April 2020): Halaman 1-22

ISSN (Print): 2541-3430, ISSN (Online): 2541-3449

Website: http://journal.iaingorontalo.ac.id/index.php/aj

\title{
Analisis Epistimologi Zakat dalam Perspektif Fiqih
}

\author{
Hamdan Ladiku \\ (IAIN Sultan Amai Gorontalo) \\ hamdanladiku@iaingorontalo.ac.id
}

\begin{abstract}
This study aims to analyze the epistemology of zakat in the perspective of fiqh. The reality of Muslims shows an imbalance between the awareness of tithe and the understanding of zakat fiqh. so the vision of zakat changing mustahik into muzakki cannot be optimized. The method used is library research, with qualitative descriptive analysis techniques.

The results showed that zakat was intended as "settlement". Zakat is required by Allah to be given to those who are entitled. The texts of the commands of zakat are analyzed through the linguistic approach of the Qur'an displaying them in three language styles (uslứb), namely: Using uslub insyâi, which is mandatory. Using the uslub tarhib (warning) aimed at people who like to accumulate wealth and do not want to pay zakat. Using uslub madh (praise/adulation) is God's praise for those who pay zakat. Philosophically, humanity is positioned into two groups, namely rich and poor, as a framework for God's plan to create a harmonious balance in realizing true justice and educating people to behave and behave fairly (ummatan wasatan).
\end{abstract}

\section{Abstrak}

Penelitian ini bertujuan untuk menganalisis epistimologi zakat dalam perspektif fiqih. Realitas umat Islam menunjukkan ketidak 
seimbangan antara kesadaran berzakat dengan pemahaman fiqih zakat. sehingga visi zakat merubah mustahik menjadi muzakki belum dapat dioptimalkan. Metode yang digunakan adalah studi pustaka (library research), dengan teknik analisis deskriptif kualitatif.

Hasil penelitian menunjukan bahwa zakat dimaksudkan sebagai "penunaian". Zakat diwajibkan oleh Allah untuk diberikan kepada mereka yang berhak. Teks-teks perintah zakat dianalisis melalui pendekatan kebahasaan al-Qur'an menampilkannya dalam tiga gaya bahasa (uslíb), yaitu: Menggunakan uslub insyâi, yang bersifat perintah. Menggunakan uslub tarhib (intimidatif/peringatan) yang ditujukan bagi orang yang suka menumpuk harta kekayaan dan tidak mau mengeluarkan zakatnya. Menggunakan Uslub madh (pujian/sanjungan) yaitu pujian Tuhan terhadap orang-orang yang menunaikan zakat. Secara filosofis realitas diposisikanya manusia menjadi dua golongan, yaitu kaya dan miskin, sebagai kerangka rencana Tuhan dalam menciptakan keseimbangan yang harmoni dalam mewujudkan keadilan yang hakiki serta mendidik manusia supaya bersikap dan berperilaku adil (ummatan wasatan).

Kata Kunci : Epistimologi, Zakat, Fiqih

\section{Pendahuluan}

Fiqih (al-fiqh) adalah salah satu displin ilmu dalam syari'at Islam yang secara spesifik menganilis dan mengurai persoalan hukum yang terkait dengan perbuatan mukallaf sekaligus menata berbagai aspek kehidupan manusia dalam semua dimensi, baik kehidupan pribadi, bermasyarakat maupun kehidupan manusia dengan TuhanNya. Terminologi fiqh sebagai hukum syari'at yang berkenaan dengan perbuataan mukallaf, eksistensinya menjadi begitu penting dan signifikan terhadap optimalisasi kewajiban zakat setiap muslim.

Kajian fiqih zakat mencakup beberapa dimensi : Pertama, dimensi ijtihad. Tujuan disyariatkan zakat adalah terwujudnya kemaslahatan untuk keadilan sosial dan kesejahteraan dengan prinsip yang kuat membantu kaum yang lemah (mustadh'afin). Dari aspek keqath'i-an ayat zakat memang tidak perlu dilakukan ijtihad. Namun, keberadaan ijtihad diperlukan untuk menerapkan aspek maqashid alsyari'ah dari ayat-ayat zakat. Ijtihad sebagai metodologi perumusan hukum zakat menempuh tiga tahapan: (1) Tanqih al-Manaat yaitu mengungkapkan atau menseleksi sifat-sifat yang berpengaruh pada hukum (al-ta'yin wa al-hadfu fi sifat al-hukm). Fungsi mujtahid adalah menentukan dan membuang sifat-sifat yang berpengaruh pada

2 | Hamdan Ladiku 
hukum, di mana setiap mukallaf wajib berijtihad pada tingkat tanqih, disebabkan sebagian keberadaan nash-nash zakat masih bersifat universal dan abstrak. Sehingga kewajiban Zakat perlu dicarikan makna operasionalnya agar lebih concrete dan applicable. (2) Takhrij al-Manat yaitu menggali hukum-hukum Zakat dari sumbernya langsung (al-Qur'an dan Hadits), baik yang bersifat pasti (qath ’i) maupun dugaan (dzanni), atau lafadz hukum zakat yang bersifat implisit maupun eksplisit. Tahapan kedua ini disebut pula ijtihad qiyasi yakni memindahkan hukum zakat atau menghubungkan furu' yang tidak ada nash-nya dengan furu' yang ada nash-nya karena kesamaan illat hukum zakat. Pada tahapan kedua ini, metode qiyas menjadi signifikan dalam proses penetapan hukum zakat. (3) Tahqiq al-Manaat yaitu merumuskan pernyataan-pernyataan yang berupa keputusan-keputusan hukum zakat yang bersifat pasti (qath'i) maupun dugaan (dzanni) atas perkembangan kasus hukum zakat yang sedang dikaji, berikut implementasinya. Pada tahapan ini, setiap produk hukum zakat hasil ijtihad hendaknya dapat diimplementasikan sesuai kemauan nash dan tuntutan realitas dalam kehidupan masyarakat.

Kedua, dimensi maqashid. Maqashid adalah jamak dari maqshid yang berarti kesengajaan dan tujuan. Sedangkan syar'iah berarti jalan menuju sumber air. Kedua kata ini digabung menjadi satu yaitu maqashid al-syari'ah. Maqashid al-Syari'ah ini merupakan tujuan ditetapkannnya hukum zakat dari sumber pertama dan utama yaitu al-Qur'an. Semua ketentuan hukum zakat dalam al-Qur'an diawali dengan terma amr dan nahy yang berimplikasi pada dua kategori dalam kajian ushul al-fiqh disebut dengan qath'i dan zhan. Ketentuan-ketentuan Allah dalam-ayat-ayat ahkam zakat mempunyai manfaat yang hakiki bagi kehidupan manusia yaitu kemaslahatan hidup. Konsep maslahat ini diakui oleh para ulama dan karenanya para ulama merumuskan sebuah kaidah cukup popular, "Di mana ada kemaslahatan di sana tendapat hukum Allah".

Zakat sebagai rukun Islam yang ketiga, disamping sebagai ibadah dan bukti dari ketundukan seseorang kepada Allah, juga mempunyai fungsi sosial yang sangat besar disamping merupakan satu tonggak perekonomian Islam. Jika zakat dapat dikelola dengan baik, baik penerimaan, pengambilannya maupun pendistribusiannya, maka akan mampu mengentaskan kemiskinan dan mengangkat derajat kesejahteraan orang-orang miskin. Diantara rukun Islam, zakat merupakan rukun Islam yang penting setelah rukun shalat. Oleh

2020.

${ }^{1}$ https://uinsgd.ac.id/berita/pentingnya-fiqh-zakat/, diakses pada 23 Maret 
karenanya sekian banyak ayat al-Quran menggandengkan perintah salat dengan perintah zakat, dan disebutkan sebanyak delapan puluh dua kali dalam al-Quran dan juga dalam banyak Hadits Nabi.

Peran zakat dalam interaksi sesama manusia (muammalah) ditegaskan oleh Norhaziah binti Nawai dan Ainulashikin binti Marzuki dalam penelitiannya, bahwa "Zakat merupakan salah satu pendapatan negara yang mempunyai fungsi sosial untuk mengurangi kesenjangan antara kelompok ekonomi kaya dan miskin". Falsafah yang menjadi dasar adalah segala kekayaan yang ada di bumi ini tidak lain milik Allah sehingga seorang muslim tidak boleh hanya memikirkan kepentingannya sendiri melainkan harus memiliki kepekaan sosial bagi orang yang membutuhkan.

Oleh karena itu, setiap muslim wajib membayar zakat maal (harta) sebesar $2,5 \%$ dari kekayaannya untuk orang-orang yang memerlukan. Potensi zakat maal ini sangatlah besar untuk penerimaan negara sehingga upaya mengoptimalisasi pengumpulan dan penyaluran zakat ini sangatlah diperlukan untuk pembangunan sumber daya manusia, pengentasan kemiskinan dan pembangunan sosial. ${ }^{2}$ Namun masalah intinya adalah bahwa realitas umat Islam menunjukkan adanya ketidak seimbangan antara kesadaran berzakat dengan pemahaman yang memadai tentang fiqih zakat. Efeknya, kesadaran pelaksanaan zakat di kalangan Umat Islam masih belum diikuti tingkat pemahaman (al-fiqih) yang memadai tentang ibadah zakat sehingga visi mulia zakat merubah mustahik menjadi muzakki belum dapat dioptimalkan.

\section{Analisis Teori Zakat}

Secara etimologis, kata zakat berasal dari kata $z a k \bar{a}$ yang artinya "tumbuh, berkah, bersih dan baik". ${ }^{3}$ Menurut lisan al-Arāb arti dasar zakat adalah suci, tumbuh, berkah dan terpuji, ${ }^{4}$ semuanya digunakan di dalam al-Quran dan al-Hadis. Dalam kitab Kifaŷătul Akhyār, disebutkan bahwa zakat menurut bahasa artinya tumbuh, berkah dan banyak kebaikan. ${ }^{5}$ Sedangkan menurut Hammudah

\footnotetext{
${ }^{2}$ Norhaziah Binti Nawai dan Ainulashikin Binti Marzuki, "The Role of Zakat in Developing Muslim Economy”, dalam Nik Salida Sulaiha Nik Saleh (Ed.), 2007, The Developmet of Economics and Muammalat Practices, (Bandar Baru Nilai, Universiti Sains Islam Malaysia (USIM), 2007), h.1.

${ }^{3}$ Ibrāhim Anis dkk., Mu'jām al-Wāsiţ I, (Mesir: Dār al-Ma'ārif, 1972), h. 396.

${ }^{4}$ Lihat al-Fādhil Jāmal al-Dīn Muhammad ibn Mukrim Ibn Mundzir, Lisān al-Arāb, Jilid I, (Beirut: Dār Shādar, tt.), h. 90-91.

${ }^{5}$ Taqiyyuddīn Abū Bakar al-Husaini, Kifāyatul Akhyār, Juz I, (Semarang:
}

4 | Hamdan Ladiku 
Abdalati, menyatakan the literal and simple meaning of zakah is purity. ${ }^{6}$ Pemaknaan sederhana dari zakat adalah kesucian. Ada juga yang mengartikan peningkatan atau perkembangan (development). Ensiklopedi al-Quran menyebutkan, dalam terminologi fiqih zakat itu mengeluarkan sebagian harta, diberikan kepada yang berhak menerimanya, supaya harta yang tinggal menjadi bersih dan mereka yang memperolehnya menjadi suci jiwa dan tingkah lakunya. ${ }^{7}$

Secara teknis zakat dimaknai sebagai : "The tehnical meaning of the word designates the annual amount in kind or coint which a Muslim with means must distribut among the rightfull beneficiaries". (Kewajiban seorang muslim mendistribusikan secara benar dan bermanfaat, sejumlah uang atau barang).

Dalam kitab Fathūl Wahāb zakat didefenisikan sebagai sesuatu nama dari harta atau badan yang dikeluarkan menurut syarat yang ditentukan. ${ }^{9}$ Sedangkan Abū Bakar bin Muhammad al-Husainy mendefinisikan bahwa zakat adalah nama bagi sejumlah harta tertentu yang telah mencapai syarat tertentu, yang diwajibkan oleh Allah untuk dikeluarkan dan diberikan kepada yang berhak menerimanya dengan persyaratan tertentu pula. ${ }^{10}$

Syaīkh Muhammad al-Nawāwī dalam karyanya al-Majmū' yang telah mengutip dari pengarang al-Hāwi menyebutkan "zakat adalah kata Arab yang sudah dikenal sebelum Islam dan lebih banyak dipakai dalam syair-syair daripada diterangkan". Daud al-Zāhiri berkata. "kata itu tidak mempunyai asal usul kebahasaan, hanya dikenal melalui agama". Pengarang al-Hāwi berkata, "pendapat itu sekalipun salah, tidak sedikit pengaruh positifnya terhadap hukumhukum zakat". ${ }^{11}$ Mazhab Hanafi mendefinisikan zakat dengan, "menjadikan sebagian harta yang khusus dari harta yang khusus sebagai milik orang yang khusus, yang ditentukan oleh syari'at karena Allah". ${ }^{12}$

Usaha Keluarga, tt.), h. 172.

${ }^{6}$ Hammudah Abdalati, Islam in Focus, (Indiana: American Trust Publication, 1980), h. 95.

${ }^{7}$ Fahruddin.HS., Ensiklopedi al-Quran, (Jakarta: Renika Cipta, 1992), h.

618.

${ }^{8}$ Hammudah Abdalati, op. cit., h 95.

${ }^{9}$ Muhammad Zakaria al-Anshāri, Fathul Wahāb, (Beirut: Dār al-Fikr, tt.), h. 102.

${ }^{10}$ Abi Bakar Muhammad al-Husainy, op. cit., h. 172.

${ }^{11}$ Syaikh Muhammad al-Nawāwi, al-Majmū', Jilid 5, (Beirut: Dār al-Fikr, tt.), h. 102.

${ }^{12}$ Wahbah al-Zuhāily, al-Fiqh al-Islāmi wa 'Adilātuhu III, (Beirut: Dār alFikr, tt.), h. 1788. 
Dasar teologis makna zakat secara bahasa dan istilah ini berkaitan erat sekali, yaitu bahwa setiap harta yang sudah dikeluarkan zakatnya akan menjadi suci, bersih, baik, berkah, tumbuh dan berkembang, sesuai dengan firman Allah dalam Q.S. al-Taubah/9: 103.

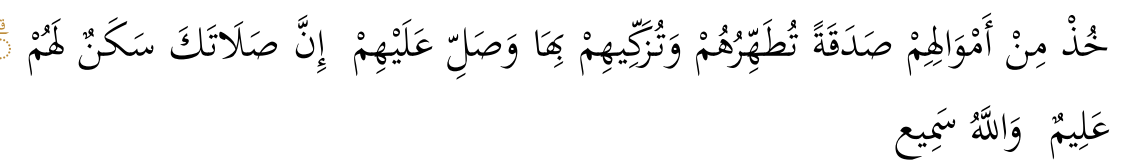

Terjemahnya:

"Ambillah zakat dari sebagaian harta mereka, dengan zakat itu kamu membersihkan dan mensucikan mereka dan mendoakan mereka. Sesungguhnya doa kamu itu (menjadi) ketentraman jiwa bagi mereka. Dan Allah Maha Mendengar lagi Mengetahui". ${ }^{13}$

Selain kata zakat, ada juga kata lain yang dipergunakan dalam al-Quran, tetapi maksud sesungguhnya adalah zakat. Kata zakat tersebut adalah sadaqah, misalnya firman Allah dalam Q.S. alTaubah/9: 60 .

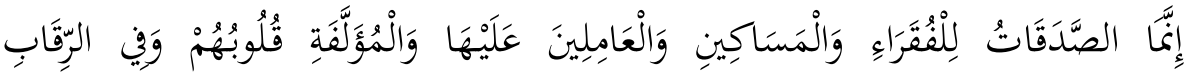

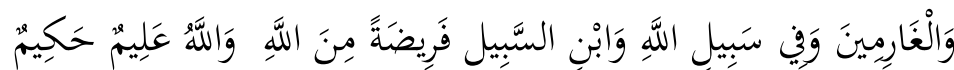

Terjemahnya :

"Sesungguhnya zakat-zakat itu, hanyalah untuk orang-orang fakir, orang-orang miskin, pengurus-pengurus zakat, para mu'allaf yang dibujuk hatinya, untuk (memerdekakan) budak, orang-orang yang berhutang, untuk jalan Allah dan untuk mereka yang sedang dalam perjalanan, sebagai suatu ketetapan yang diwajibkan Allah, dan Allah Maha Mengetahui lagi Maha Bijaksana". ${ }^{14}$

Zakat dinamakan sedekah karena tindakan itu akan menunjukkan kebenaran (şidq) seorang hamba dalam beribadah dan melakukan ketaatan kepada Allah SWT. Adapun kata infak, kadangkalanya juga dimaksudkan zakat ${ }^{15}$ sebagaimana firman Allah dalam Q.S.al- Baqarah/2:267.

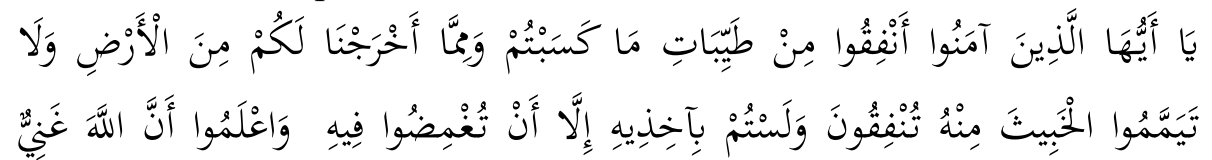

\footnotetext{
${ }^{13}$ Departemen Agama RI, Al-Qur'an dan Terjemahnya, (Surabaya: CV. Jaya Sakti, 1989), h. 297.

${ }^{14}$ Ibid., h. 288.

${ }^{15}$ Didin Hafidhuddin, Panduan Praktis tentang Zakat, Infak, Sedekah, (Jakarta: Gema Insani Press, 1998), h. 15.

6 | Hamdan Ladiku
} 
Terjemahnya :

"Hai orang-orang yang beriman, nafkahkanlah di jalan Allah sebagian dari hasil usahamu yang baik-baik dan sebagian dari apa yang kamu keluarkan dari bumi untuk kamu". ${ }^{16}$

Ibnu Jarir al-Ţābary menafsirkan kata anfiqū pada ayat tersebut dengan zakka wa taşaddaqu. Adapun yang dimaksud dengan kata alŢaỹibat, adalah al-jiyād. Dengan demikian maka tafsir dari ayat tersebut adalah "zakatilah harta-hartamu yang engkau peroleh dengan halal, dan berilah zakatmu berupa emas dan perak yang baik-baik (kadar karatnya tinggi), bukan yang rendah". ${ }^{17}$ Al-Wāhidy juga menafsirkan kata anfiqū dengan zakat. ${ }^{18}$

Infak kalau tidak mengandung arti zakat maka dalam terminologi fiqih berarti mengeluarkan sebagian dari harta atau pendapatan untuk suatu kepentingan yang diperintahkan ajaran Islam. Jika zakat ada nisabnya, infak tidak mengenal nisab. Infak dikeluarkan oleh setiap orang yang beriman, baik yang berpenghasilan tinggi, rendah, apakah ia di saat lapang maupun sempit. ${ }^{19}$ Jika zakat harus diberikan kepada mustahik, maka infak boleh diberikan kepada siapapun.

\section{Landasan Legal Teologis Zakat.}

Kata zakat dalam bentuk ma'rifah disebut tiga puluh kali di dalam al- Qur'an, diantaranya dua puluh tujuh kali disebutkan dalam satu ayat bersama salat, dan hanya satu kali disebutkan dalam konteks yang sama dengan salat tetapi tidak di dalam satu ayat, yaitu firman Allah dalam Q.S. al-Mu'minun/23: 2 - 4.

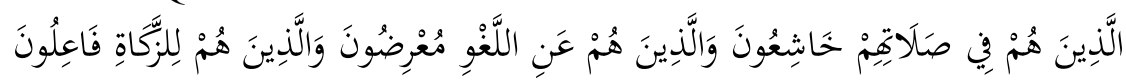

Terjemahnya :

"Orang-orang yang khusyu' dalam sembahyangnya, dan orang-orang yang menjauhkan diri dari perbuatan dan perkataan yang tiada berguna, dan orang-orang yang menunaikan zakat". ${ }^{20}$

\footnotetext{
${ }^{16}$ Departemen Agama RI., op. cit., h. 67.

${ }^{17}$ Ibnu Jarir al-Țābary, Jāmi' al-Bayā 'an Ta'wīl al-Quran III, (Beirut: Dār al-Fikr, 1998), h. 80.

${ }^{18}$ Abī al-Hasan al-Wāhidy, Asbāb al-Nuzūl, (Mesir: Mustāfa al-Bāby alHālaby, 1968), h. 48.

${ }^{19}$ Departemen Agama RI., op. cit., h. 98.

${ }^{20}$ Ibid., h. 526.
} 
Bila diperiksa ketiga puluh kali zakat disebutkan itu, delapan terdapat di dalam surat yang turun di Makkah dan selebihnya surat yang turun di Madinah. Sebagian ahli mengatakan bahwa kata zakat yang selalu dihubungkan dengan salat terdapat pada 82 tempat di dalam al-Qur'an. ${ }^{21}$ Dalam perspektif Fiqih, kewajiban zakat adalah hal yang qath'i (pasti). Persoalan Ini dapat diketahui dari agama secara tak terbantahkan dan orang yang mengingkarinya adalah kafir. Perintah menunaikan zakat dalam al-Qur'an, disebutkan di 33 tempat. Sepuluh tempat diawal ayat dan 23 tempat disebut dalam rangkaian ayat. Perintah untuk berinfak secara umum juga disebutkan dalam alqur'an di 103 tempat. Dua puluh dua di Mekkah dan 81 di Madinah. Zakat tentu termasuk dalam infak secara umum. Zakat diwajibkan di Mekkah, hanya saja saat itu belum ada ketentuan harta apa yang wajib dizakati, berapa nishab syar'inya dan berapa ukuran zakat yang wajib dikeluarkan, Semua ketentuan itu tidak ada karena muslim saat itu mulia dan dermawan. Selanjutnya, ukuran zakat dan penjelasannya secara terperinci baru diwajibkan pada tahun kedua hijriyah menurut pendapat yang masyhur. ${ }^{22}$

Zakat adalah rukun finansial sosial, satu dari lima rukun Islam, dan karena zakat (bersamaan dengan kalimat tauhid dan mendirikan shalat) seseorang masuk Islam dan termasuk dalam jamaah kaum muslimin, berhak atas ukhuwah, dan tergabung dalam barisan mereka seperti yang Allah firmankan:

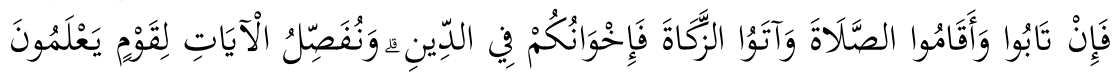

Terjemahnya :

Jika mereka bertobat, mendirikan shalat, dan menunaikan zakat maka mereka itu adalah saudara-saudaramu. Dan Kami menjelaskan ayatayatitu bagi kaum yang mengetahui.,"23

Karena pentingnya kedudukan zakat dalam Islam, Allah mendorong secara luas untuk menunaikan zakat dan berinfak untuk orang-orang yang memerlukan. Zakat membersihkan hati orang-orang kaya dari penyakit kikir dan bakhil, di samping membersihkan mereka dari dosa dan mengembangkan harta mereka. ${ }^{24}$

Rasulullah menegaskan, Sungguh Allah menerima sedekah dan mengambilnya dengan tangan kanan-Nya lalu dia

\footnotetext{
${ }^{21}$ Lihat, Muhammad Fuad Abdul Baqi, Al-Mu'jam Al-Mufahras Li Alfaz al-Qur'an, pada kata "zakat"

${ }^{22}$ Sayyid Sabiq, Fikh al-Sunnah, jilid III, (Kuwait: Dâr al-Bayân, 1998), h. 157.

${ }^{23}$ Departemen Agama RI., op. cit., h. 279.

${ }^{24}$ Ibid.
}

8 Hamdan Ladiku 
mengembangkannya untuk salah seorang dari kalian, sebagaimana salah seorang dari kalian merawat anak untanya. Sesungguhnya, sedekah jatuh di tangan Allah sebelum jatuh ditangan orang yang meminta. Orang yang tidak menunaikan zakat tidak terpisah dari orang-orang kafir. ${ }^{25}$ Salah satu sifat orang kafir adalah enggan menunaikan zakat dan tidak percaya akan hari akhir.

Landasan hukum lain atas legalitas dan anjuran berzakat ialah firman Allah dalam Q.S. al-Ma'ârij/70: 24 - 25.

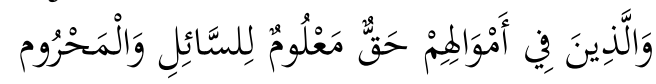

Terjemahnya :

"Dan orang-orang yang dalam hartanya tersedia bagian tertentu.Bagi orang (miskin) yang meminta dan orang yang tidak mempunyai apaapa (yang tidak mau meminta)." 26

An-Nasafi menjelaskan bahwa yang dimaksudkan ayat ini adalah zakat, karena ukuran zakat telah diketahui, atau sedekah yang diwajibkan seseorang terhadap diri sendiri yang ditunaikan di waktuwaktu tertentu. "Bagi orang (miskin) yang meminta", artinya adalah orang yang meminta-minta. "Dan orang yang tidak mempunyai apaapa (yang tidak mau meminta)". Yaitu, orang yang menjaga diri untuk meminta-minta sehingga ia dikira memiliki kecukupan, padahal ia terhalang dari nikmat. ${ }^{27}$ Ibnu Katsir menjelaskan bahwa, di dalam harta mereka terdapat bagian tertentu untuk orang-orang yang memerlukan bantuan. ${ }^{28}$

Di sisi lain kita temukan, Allah menjadikan harta yang diberikan kepada fakir miskin yang berhak sebagai kewajiban untuk Allah. Tujuannya adalah agar orang yang berzakat tidak mengungkitungkit orang miskin, sebab orang miskin sebenarnya telah membantunya untuk mendekatkan diri kepada Allah. Allah berfirman dalam Q.S. al Muzammil/73: 20.

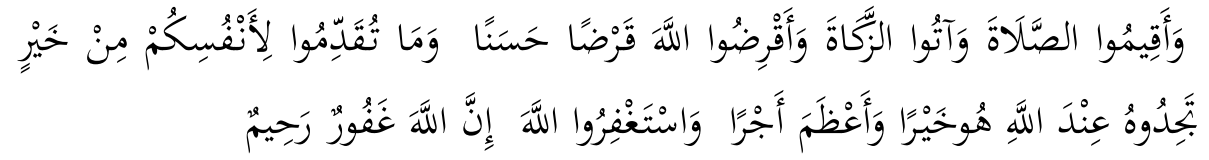

Terjemahnya :

"...Dan dirikanlah shalat, tunaikanlah zakat, dan berikanlah pinjaman kepada Allah pinjaman yang baik. Dan kebaikan apa saja yang kamu

\footnotetext{
${ }^{25}$ Lihat Quraish Shihab, Tafsir al-Misbah, Cet. III (Jakarta: Lentera hati, 2005), h. 705-707.

${ }^{26}$ Departemen Agama RI., op. cit., h. 974.

${ }^{27}$ Ali Mahmud Uqaily, op. cit., h. 21.

${ }^{28}$ Abdullah Bin Muhammad... op. cit., h. 329.
} 
perbuat untuk dirimu niscaya kamu memperoleh (balasan) nya di sisi Allah sebagai balasan yang paling baik dan yang paling besar pahalanya. Dan mohonlah ampunan kepada Allah. Sesungguhnya Allah Maha pengampun lagi Maha Penyayang."29

Itulah beberapa ayat yang menjadi landasan teologis sekaligus motifasi ditunaikannya zakat. Amalan ini menjadi wajib, karena zakat memiliki kekhasan agung dan posisi luhur dalam Islam. Allah berfirman dalam Q.S. al-Baqarah/2: 261.

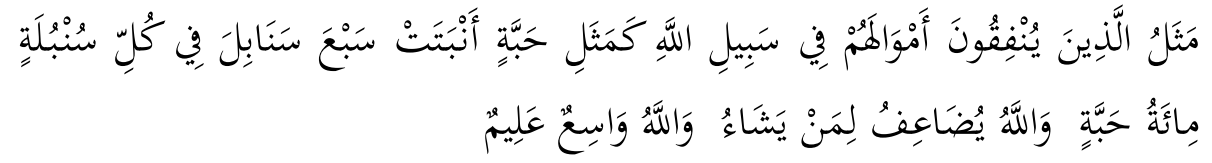

Terjemahnya :

"Perumpamaan nafkah yang dikeluarkan oleh orang-orang yang menafkahkan hartanya dijalan Allah adalah serupa dengan sebutir benih yang menumbuhkan tujuh bulir, pada tiap-tiap bulir seratus biji. Allah melipatgandakan (ganjaran) bagi siapa yang dia kehendaki. Dan Allah maha luas (karunia-nya) lagi Maha Mengetahui." 30

Harta yang diinfakan dijalan Allah akan tumbuh berkembang dan berlipat ganda hingga mencapai 700 kali lipat, dan Allah melipatgandakan untuk siapapun yang Dia kehendaki. ${ }^{31}$ Di lain pihak, kita temukan ancaman keras dan terus menerus untuk yang enggan membayar zakat. Allah memberi peringatan kepada mereka yang enggan menunaikan zakat dengan siksa yang pedih. Mereka adalah orang-orang yang menyimpan emas dan perak tanpa ditunaikan zakatnya, Allah berfirman dalam Q.S. al-Taubah/9: 34-35.

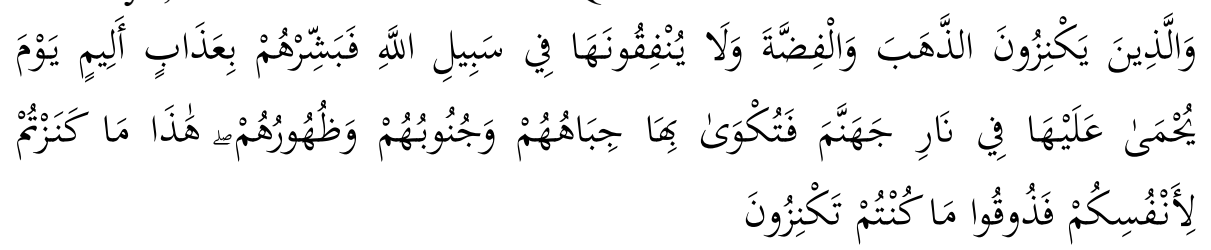

Terjemahnya :

“...Dan orang-orang yang menyimpan emas dan perak dan tidak menafkahkan pada jalan Allah, maka beritahukan kepada mereka (bahwa mereka akan mendapat) siksa yang pedih. Pada hari dipanaskan emas dan perak itu dalam neraka jahanam, lalu dibakar dengannya dahi mereka, lambung, dan punggung mereka (lalu dikatakan) kepada mereka, inilah harta bendamu yang kamu simpan

\footnotetext{
${ }^{29}$ Departemen Agama RI., loc. cit.

${ }^{30}$ Ibid., h. 65.

${ }^{31}$ Lihat Sayyid Qutub, Fi-Zhilali al-Qur'an (Kairo: Dâr al-Syuruq, 1982), h. $65-67$

10 | Hamdan Ladiku
} 
untuk dirimu sendiri, maka, rasakanlah sekarang (akibat dari) apa yang kamu simpan itu." 32

Ketika kita membaca penafsiran ayat di atas, kita temukan "Dan orang-orang yang menyimpan emas dan perak," kemungkinan nash ini mengisyaratkan perbuatan sebagian besar pendeta dan rahib. Ini berdasarkan petunjuk menyatunya dua sifat tercela yang terdapat pada mereka, yaitu menerima suap dan menimbun harta tanpa menginfakkannya di jalan Allah. Siapa pun dari kalangan muslimin yang menyamai sifat-sifat mereka yang tercela, berarti ia termasuk dalam kategori tersebut. Selain itu, dapat dimungkinkan juga bahwa yang dimaksud nash ayat tersebut ialah kaum muslimin yang menimbun harta tanpa dikeluarkan zakatnya. Kaum muslimin semacam ini dikaitkan dengan ahli kitab yang menerima suap untuk memperberat hal tersebut. ${ }^{33}$

Dikatakan kepada mereka, inikah yang dahulu engkau simpan agar bisa memberi manfaat kepadamu dan engkau tidak tahu justru dengan menyimpannya malah membahayakan dirimu sendiri?" Ini adalah satu bentuk celaan. "Maka, rasakanlah sekarang akibat dari apa yang kamu simpan."34

Ibnu Umar berkata, "Harta yang dikeluarkan zakatnya bukan termasuk harta simpanan meski berada di bawah tujuh bumi. Sedangkan harta yang terlihat dan tidak dikeluarkan zakatnya, itulah harta simpanan." 35

Imam Ahmad, meriwayatkan bahwa Hasan Bin Athiyah berkata, "Suatu ketika Saddad bin Aus bepergian lalu singgah disebuah rumah. Ia berkata kepada budaknya, Carikan syufrah ${ }^{36}$ untuk kami cumbu. Budaknya pun mengingkari hal itu lalu ia berkata, Tidaklah aku mengucapkan suatu kata sejak aku masuk Islam melainkan aku mengucapkannya dengan hati-hati, kecuali kata-kataku ini. Karena itu, jangan mengingat hal itu dariku dan hafalkan yang akan kukatakan padamu. Aku pernah mendengar Rasulullah bersabda, Tatkala orang-orang menimbun emas dan perak, simpanlah kalimatkalimnt berikut :"Ya Allah, aku memohon keteguhan kepada-Mu dalam urusan agama dan keteguhan di atas petunjuk. Aku memohon kepada-Mu agar aku mensyukuri nikmat-Mu. Aku memohon kepada$\mathrm{Mu}$ agar aku menyembah-Mu dengan baik. Aku memohon hati yang

\footnotetext{
${ }^{32}$ Departemen Agama RI., op. cit., h. 283.

${ }^{33}$ Ahmad Mustafa al-Maragi, h. 182-183.

${ }^{34}$ Ibid, h. 184.

${ }^{35}$ Al-Bani, Mukhtashar Shahihul Bukhari, Cet. I (Beirut, Maktabah alMushannaf Abdurazlami, 1399 H), h. 714.

${ }^{36}$ Wanita yang dibayar dengan mahar yang sedikit.
} 
bersih kepada-Mu. Aku memohon lisan yang jujur kepada-Mu. Aku memohon kepada-Mu hal terbaik yang Engkau ketahui. Aku berlindung kepada-Mu dari hal terburuk yang Engkau ketahui. Dan aku memohon ampunan kepada-Mu untuk (dosa) yang Engkau ketahui, Sesungguhnya Engkau Maha Mengetahui yang gaib. ${ }^{37}$

Imam Ahmad meriwayatkan dari Abdullah bin al-shamit. Suatu ketika, ia sedang bersama Abu Dzar yang sedang memberikan sedekah. Dan saat itu, ia bersama budak perempuan. Budak itu menuntaskan seluruh keperluannya hingga masih tersisa tujuh (dirham). Abu Dzar kemudian memerintahkan budak itu agar membeli ikan. Abdullah bin al-Shamit kemudian berkata kepada Abu Dzar, Andai saja kau menyimpan sisa itu untuk suatu keperluan atau untuk tamu yang singgah di rumahmu. Mendengar perkataan Abdullah bin al-Shamit, Abu Dzar kemudian menuturkan, Sungguh, Rasulullah berwasiat kepadaku, emas atau perak yang membuat pemiliknya kikir terhadapnya maka itu adalah bara api bagi pemiliknya hingga ia menginfakkannya di jalan Allah. ${ }^{38}$

Itulah sebagian ayat al-qur'an dan al-Hadits yang menjelaskan anjuran Allah untuk menunaikan zakat dan ancaman keras atas sikap enggan mengeluarkan zakat yang merupakan rukun sosial dari lima rukun Islam. Semua legalitas ini menunjukan bahwa zakat adalah perhatian sosial dari orang-orang kaya untuk orang-orang miskin agar masyarakat miskin dapat mereguk kesejahteraan berbasis persaudaraan, cinta dan kasih sayang.

Berikut beberapa hadits Nabi yang menjelaskan perihal wajibnya zakat, antara lain :

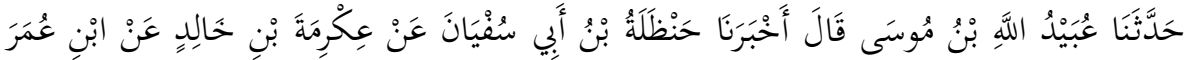

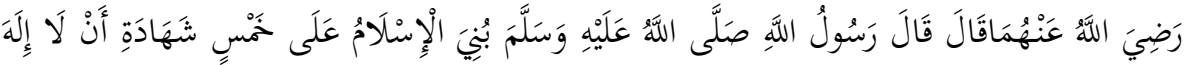

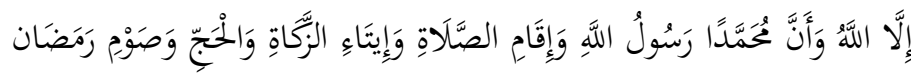

Terjemahnya :

"Telah menceritakan kepada kami Abdullah bin Musa dia berkata, telah mengabarkan kepada kami Hanzhalah bin Abu Sufyan dari 'Ikrimah bin Khalid dari Ibnu Umar berkata: Rasulullah shallallahu 'alaihi wasallam bersabda: "Islam dibangun diatas lima (landasan); persaksian tidak ada ilah selain Allah dan sesungguhnya Muhammad

\footnotetext{
${ }^{37}$ Ahmad bin Abdurahman al-Banna, Fathu al-Rabbani Musnad Ahmad bin Hanbal, Cet. I, (Cairo, al-Babi al-Halabi, 1370 H), h. 171.

${ }^{38}$ Ahmad bin Abdurahman al-Banna, op. cit., h. 2142.
} 
utusan Allah, mendirikan shalat, menunaikan zakat, haji dan puasa Ramadlan". ${ }^{39}$

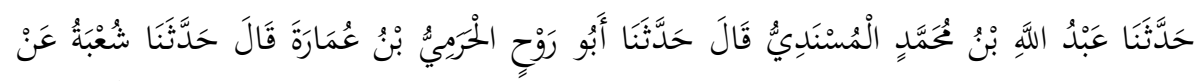

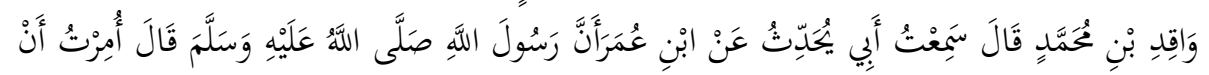

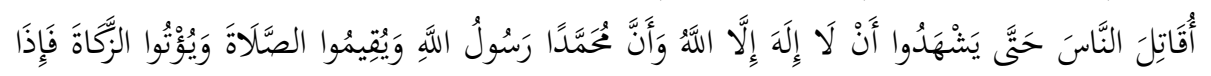

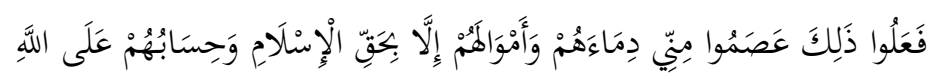

Terjemahnya :

"Telah menceritakan kepada kami Abdullah bin Muhammad Al Musnadi dia berkata, Telah menceritakan kepada kami Abu Rauh Al Harami bin Umarah berkata, telah menceritakan kepada kami Syu'bah dari Waqid bin Muhammad berkata; aku mendengar bapakku menceritakan dari Ibnu Umar, bahwa Rasulullah shallallahu 'alaihi wasallam telah bersabda: "Aku diperintahkan untuk memerangi manusia hingga mereka bersaksi; tidak ada ilah kecuali Allah dan bahwa sesungguhnya Muhammad adalah utusan Allah, menegakkan shalat, menunaikan zakat. Jika mereka lakukan yang demikian maka mereka telah memelihara darah dan harta mereka dariku kecuali dengan haq Islam dan perhitungan mereka ada pada Allah ". ${ }^{40}$

Jabir bin Abdullah berkata, Aku berjanji setia kepada Nabi untuk mendirikan shalat, menunaikan zakat, dan menasihati setiap muslim.

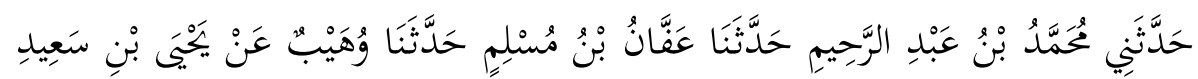

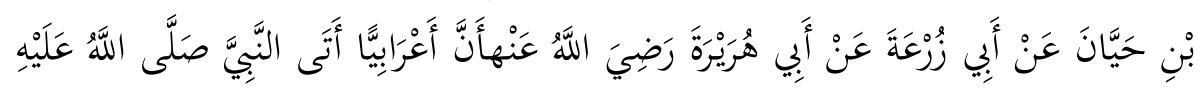

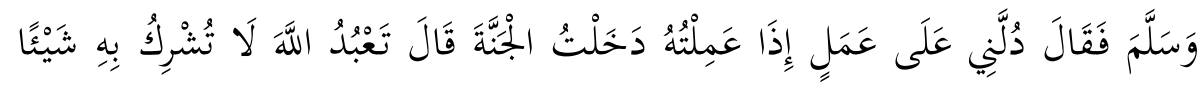

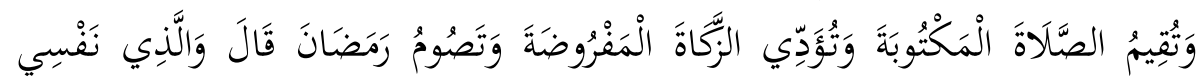

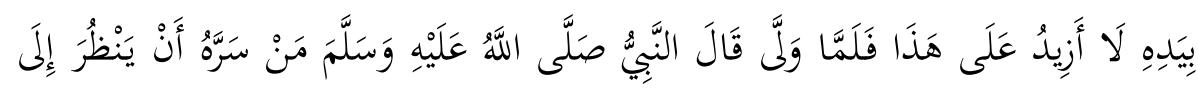

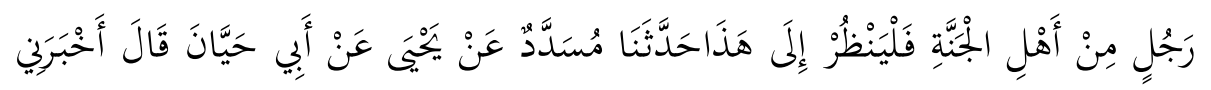

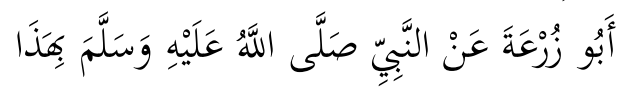

Terjemahnya :

\footnotetext{
${ }^{39}$ Al-Bani, MukhtasharShahihul Bukhâri, dalam Hadits Encylopedia, [CD ROM], Lidya Pustaka i-Sowtware, 2010, hadits no. 7.

${ }^{40}$ Ibid., hadits no. 24.
} 
"Telah menceritakan kepada saya Muhammad bin 'Abdur Rahim telah menceritakan kepada kami 'Affan bin Muslim telah menceritakan kepada kami Wuhaib dari Yahya bin Sa'id bin Hayyan dari Abu Zur'ah dari Abu Hurairah radliallahu 'anhu; Ada seorang Arab Badui menemui Nabi Shallallahu'alaihiwasallam lalu berkata,: "Tunjukkan kepadaku suatu amal yang bila aku kerjakan akan memasukkan aku kedalam surga". Nabi Shallallahu'alaihiwasallam bersabda: "Kamu menyembah Allah dengan tidak menyekutukanNya dengan suatu apapun, kamu mendirikan shalat yang diwajibkan, kamu tunaikan zakat yang wajib, kamu mengerjakan shaum (puasa) bulan Ramadhan. Kemudian orang Badui itu berkata,: "Demi Dzat yang jiwaku berada di tanganNya, aku tidak akan menambah dari perintah-perintah ini". Ketika hendak pergi, Nabi Shallallahu'alaihiwasallam bersabda: "Siapa yang berkeinginan melihat laki-laki penghuni surga maka hendaklah dia melihat orang ini". Telah menceritakan kepada kami Musaddad dari Yahya dari Abu Hayyan berkata, telah mengabarkan kepada saya Abu Zur'ah dari Nabi Shallallahu'alaihiwasallam sepeti hadits ini. ${ }^{41}$

Ahmad dan Turmudzi meriwayatkan dari Abu Hurairah bahwa Rasulullah bersabda, "Sungguh, Allah menerima sedekah dan mengambilnya dengan tangan kanan-Nya lalu mengembangkannya seperti salah seorang dari kalian merawat anak untanya atau unta yang telah disapih bahkan, satu suapan berkembang menjadi seperti gunung uhud. Pembenaran hal itu terdapat dalam kitab Allah yaitu firman-nya:"Tidaklah mereka mengetahui bahwa Allah menerima tobat dari hamba-hamba-Nya dan menerima zakat... ,42 (uslúb: ${ }^{43}$ yaitu :

Al-Quran menampilkan kata zakat dalam tiga gaya bahasa

a. Menggunakan uslub insyâi, yaitu berupa perintah, seperti terlihat antara lain pada ayat 43, 83 dan 110 surah al-Baqarah, ayat 33 surah al-Ahzab, ayat 78 surah al-Hajj, ayat 56 surah al-Nur, dan surah 73/al-Muzammil;20, yaitu menggunakan kata انفقا atau اتو ا misalnya:

$$
\text { و اتاهم من مال الله ... و اتو الزكاة...انفقو ا من طيبات ما كسبتم }
$$

Dalam ayat lain digunakan pula kata kerja dengan menggunakan kata خذ itu perintah untuk mengambil atau memungut zakat

\footnotetext{
${ }^{41}$ Ibid,. Hadits no. 1310.

${ }^{42}$ Ibid., Hadits no 2248.

${ }^{43}$ Lihat Quraish Shihab, TafsirAmanah, (Jakarta: Pustaka Kartini, 1992), h.
}

9.

14 | Hamdan Ladiku 
(shadaqah) seperti terdapat dalam surat al-Taubah ayat 103. Sasaran perintah ini ditujukan kepada penguasa (amil zakat) untuk memungut dan mengelola harta zakat dari para wajib zakat.

b. Menggunakan uslub targhib (motivatif), yaitu suatu dorongan untuk tetap mendirikan shalat dan membayarkan zakat yang merupakan ciri orang yang benar iman dan taqwa, kepada mereka dijanjikan akan memperoleh ganjaran berlipat ganda dari Tuhan. Salah satu bentuk tersebut di atas dapat dilihat dari firman Allah dalam Q.S alBaqarah/2: 277.

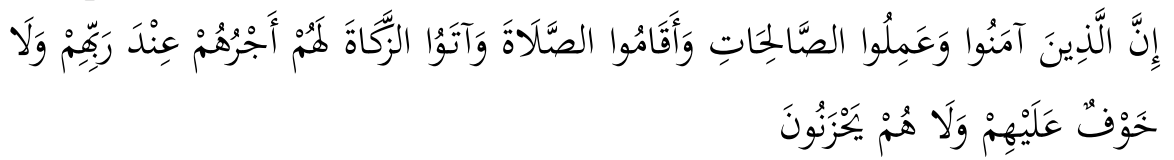

Terjemahnya “

"Sesungguhnya orang-orang yang beriman, mengerjakan amal saleh, mendirikan shalat dan menunaikan zakat, mereka mendapat pahala di sisi Tuhannya. Tidak ada kekhawatiran terhadap mereka dan tidak (pula) mereka bersedih hati. ${ }^{44}$

c. Menggunakan uslub tarhib (intimidatif/peringatan) yang ditujukan bagi orang yang suka menumpuk harta kekayaan dan tidak mau mengeluarkan zakatnya. Ancaman tersebut antara lain sebagaimana firman Allah dalam Q.S. al-Taubah/9: 34-35.

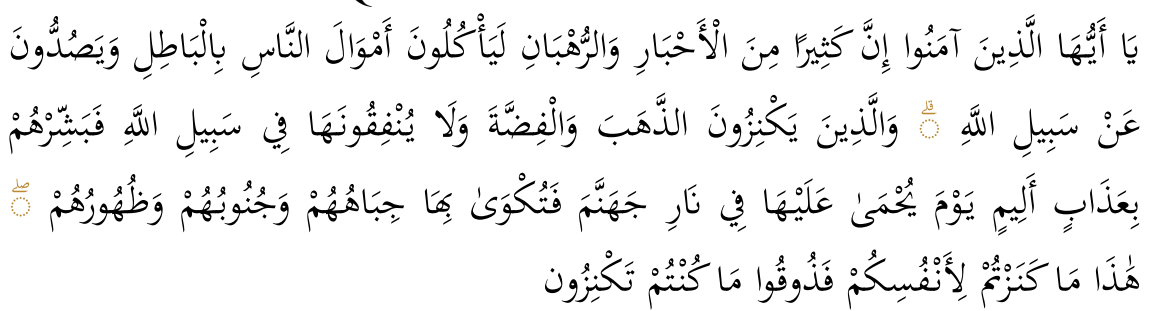

Terjemahnya :

"Hai orang-orang yang beriman, sesungguhnya sebahagian besar dari orang-orang alim Yahudi dan rahib-rahib Nasrani benar-benar memakan harta orang dengan jalan batil dan mereka menghalanghalangi (manusia) dari jalan Allah. Dan orang-orang yang menyimpan emas dan perak dan tidak menafkahkannya pada jalan Allah, maka beritahukanlah kepada mereka, (bahwa mereka akan mendapat) siksa yang pedih, pada hari dipanaskan emas perak itu dalam neraka jahannam, lalu dibakar dengannya dahi mereka, lambung dan punggung mereka (lalu dikatakan) kepada mereka: "Inilah harta bendamu yang kamu simpan untuk dirimu sendiri,

\footnotetext{
${ }^{44}$ Departemen Agama RI, op. cit., h. 69.
} 
maka rasakanlah sekarang (akibat dari) apa yang kamu simpan itu". 45

d. Menggunakan Uslub madh (Pujian/sanjungan) yaitu pujian Tuhan terhadap orang-orang yang menunaikan zakat. Mereka disanjung sebagai penolong (wali) yang disifati dengan sifat ketuhanan, kerasulan dan orang-orang yang beriman, karena kesanggupannya memberikan harta yang disenanginya berupa zakat kepada orang lain. $^{46}$ Ayat dalam bentuk tersebut dijumpai dalam Q.S. alMaidah/5: 55.

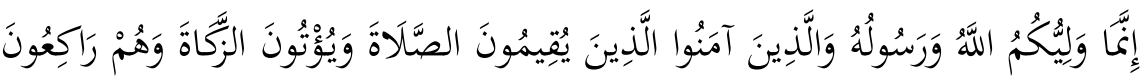

Terjemahnya :

"Sesungguhnya penolong kamu hanyalah Allah, Rasul-Nya, dan orang-orang yang beriman, yang mendirikan shalat dan menunaikan zakat, seraya mereka tunduk (kepada Allah)". 47

Berdasarkan kajian landasan teologis al-Qur'an maupun alHadits tersebut di atas terutama yang menempatkan kata zakat mengiringi kata shalat, maka dapat diikhtisarkan bahwa status zakat sebagai ibadah wajib, sama pentingnya seperti shalat. Ini berarti bahwa zakat merupakan salah satu sendi dari tiang utama bangunan Islam. Demikian zakat sebagai rukun Islam. Meninggalkan zakat bagi yang mampu batallah status orang sebagai penganut Islam yang baik.

\section{Landasan Historis Zakat}

Nabi Muhammad SAW diutus Tuhan ke dunia ini dengan tujuan antara lain memperbaiki akhlak manusia yang ketika itu sudah mencapai ambang batas kerusakan yang sangat membahayakan bagi masyarakat. Kerusakan tersebut terutama disebabkan oleh sikap dan perilaku golongan penguasa dan pemilik modal yang umumnya bersikap zalim dan sewenang-wenang. Orang kaya mengeksploitasi golongan lemah dengan berbagai cara seperti sistem riba, berbagai bentuk penipuan, dan kejahatan ekonomi lainnya. Dalam suasana memuncaknya praktek riba inilah turun beberapa ayat al-Quran yang menganjurkan supaya orang-orang kaya membantu orang-orang lemah melalui zakat, infaq dan sedekah.

Dari aspek historis, kewajiban berzakat sudah disyariatkan Tuhan kepada Para Nabi dan Rasul sebelumnya, sebagaimana yang telah dilaksanakan oleh Nabi Ibrahim as. Hal ini diungkap al-Quran

\footnotetext{
${ }^{45}$ Departemen Agama RI, loc. cit.

${ }^{46}$ Lihat Al-asfahani, Al-Mufradât fĩ Qarĩbi al-Qur'an, (Beirut: Dâr alMa'ârif, tt.), h. 9.

${ }^{47}$ Departemen Agama RI, op. cit., h. 169. 
dalam surah al-Anbiya/21: 73.

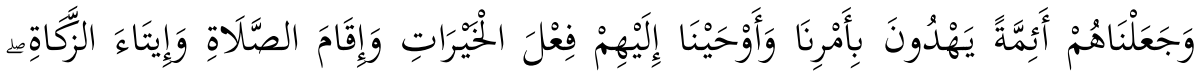

$$
\begin{aligned}
& \text { وَكَانُوا لَنَا عَابِيدِينَ }
\end{aligned}
$$

Terjemahnya :

“... dan telah kami wahyukan kepada mereka supaya mengerjakan kebajikan, mendirikan sholat, menunaikan zakat, dan kepada Kamilah mereka harus selalu mengabdi". 48

Demikian pula atas umat Nabi Ismail sebagaimana dituturkan Q.S. Maryam/19: 55.

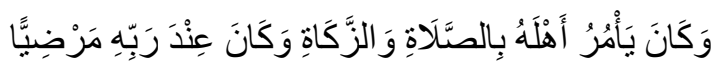

Terjemahnya :

Dan dia (Nabi Ismail) menyuruh umatnya untuk mendirikan sholat dan menunaikan zakat... ${ }^{49}$

Bahkan terhadap Bani Israil, umat Nabi Musa, syariat zakat diterapkan seperti diungkapkan dalam Q.S. al-Baqarah/2: 83.

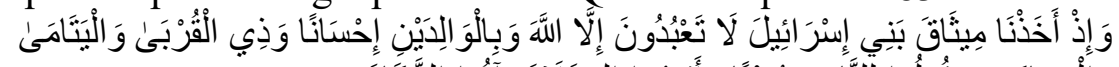

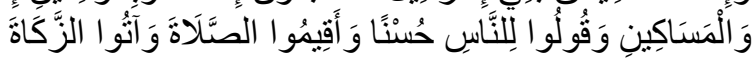

Terjemahnya :

"Dan ingatah ketika Kami mengambil janji dari Bani Israil, yaitu janganlah kamu menyembah selain Allah, dan berbuat baiklah terhadap ibu bapak, kaum kerabat, anak-anak yatim dan orang-orang miskin serta ucapkan kata-kata yang baik kepada manusia, dirikan shalat dan tunaikan zakat...". 50

Nabi Isa ketika masih dalam buaian telah menyampaikan suatu ucapan sebagaimana tertera dalam Q.S.Maryam/19: 31.

Terjemahnya :

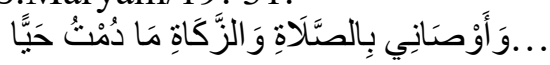

“... Dan dia (Allah) memerintahkan kepadaku mendirikan shalat dan menunaikan zakat selama aku hidup".51

Demikian pula terhadap Ahli Kitab pada umumnya kewajiban zakat telah diterapkan bersamaan dengan kewajiban shalat sebagaimana diungkap Q.S.al-Bayyinah/98: 5.

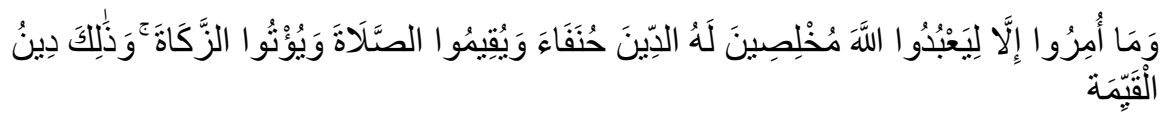

${ }^{48}$ Ibid., h. 504 .

${ }^{49}$ Ibid., h. 468.

${ }^{50}$ Ibid., h. 23.

${ }^{51}$ Ibid., h. 466. 
Terjemahnya :

"Padahal mereka tidak disuruh kecuali menyembah Allah dengan memurnikan ketaatan kepada-Nya, menjalankan agama yang lurus, dan supaya mereka mendirikan shalat dan menunaikan zakat; dan yang demikian itulah agama yang lurus. $^{52}$

Namun demikian penerapan zakat pada agama-agama sebelum Islam belum merupakan suatu kewajiban mutlak yang ilzami, tetapi ia bersifat solidaritas sosial dan rasa belas kasihan (charity) dalam rangka menyantuni orang miskin. Barulah dalam syariat Islam zakat ditetapkan menjadi suatu kewajiban yang bersifat ilzami-ijbari (kewajiban mutlak) sehingga dijadikan rukun Islam.

\section{Landasan Logika, Filosofis dan Sosiologis Zakat}

Ibadah zakat, meskipun ia sebagai kewajiban agama berdasarkan nas normatif tetapi ia dapat dipahami secara logika dan filosofis. Landasan logika dan filosofis ini meliputi pertimbangan logika tentang mengapa zakat itu diwajibkan, apa fungsi dan peranannya, sehingga diyakini bahwa ibadah zakat sangat logis sesuai dengan pertimbangan akal yang sehat dan hati nurani yang beriman serta dilihat pula dari sisi hikmah dan rahasia yang terkandung dalam syariat zakat.

Berikut ini dikemukakan beberapa argumen logika oleh beberapa pakar diantaranya pendapat yang menyatakan, Allah mewajibkan setiap orang yang masih mampu bekerja dan berusaha agar giat mencari rezeki guna memenuhi kebutuhan hidupnya. Tetapi tidak semua orang mempunyai kesanggupan dan kemampuan bekerja atau berusaha, dan tidak semua orang mempunyai harta secara mudah seperti harta warisan atau mempunyai kaum kerabat yang kaya yang mau menangggung biaya hidupnya, dan berbagai problema sosial sebagian manusia, sehingga mereka tenggelam dalam kemelaratan dan kemiskinan.

Sementara sebagian manusia yang hidup dalam serba kecukupan Tidak memikirkan nasib mereka yang miskin, padahal Allah telah menetapkan hak mereka yang miskin itu di dalam harta orang-orang kaya secara tegas dan pasti, yaitu melalui syariat zakat, infak dan kewajiban bidang harta lainnya ${ }^{53}$.

Al-Thayyar memaparkan argumen logika zakat, bahwa akal

\footnotetext{
${ }^{52}$ Ibid ., h. 1086.

${ }^{53}$ Al-Qardhawi, Musykilat al-Faqr wa kaifa 'alajaha al-Islam, Cet. II;
} (Cairo: 1975 Maktabat Wahbah, 1975), h. 68. 
sehat tidak bisa menerima dua dikotomi, yaitu adanya orang mati terlalu kenyang karena banyaknya yang dimakan, dan adanya orang yang mati kelaparan karena tidak ada yang bisa dimakan. Selanjutnya dia mengemukakan, bahwa akal sehat tidak dapat menerima adanya orang yang memberikan kelebihan makanannya kepada anjing, sementara ada orang orang yang mengais rizki kesana kemari tetapi tidak mendapatkannya. ${ }^{54}$

Muhammad Abu Zahrah mengemukakan pandangannya bahwa dengan memberikan zakat dari orang kaya, si miskin merasa dibantu dan berterima kasih dan dapat saling menolong. Orang miskin diberi zakat akan mendatangkan kenyamanan bagi orang kaya, kalau tidak, orang miskin akan jadi musuh bagi orang kaya dan tidak mustahil akan merampok harta kekayaannya.

Dilihat dari aspek sosiologis, manusia adalah makhluk sosial (zoon politicion), memiliki rasa kemanusiaan, belas kasihan dan tolong-menolong. Akal manusia yang sehat pasti cenderung kepada sifat-sifat seperti di atas, dan menolak sikap dan perilaku individualistis, egoistik dan homohomini lupus. Justru itulah mengapa ibadah zakat dibagi dalam dua bentuk, yaitu zakat mal (harta) dan zakat fitrah (jiwa). Zakat merupakan pemberian materi yang tidak mudah dipahami, oleh karena itu zakat tidak mudah diamalkan, kecuali apabila terlebih dahulu dipahami dan diyakini aspek-aspek keuntungan dan dampaknya.

Secara sosiologis, zakat adalah refleksi dari rasa kemanusiaan, keadilan, keimanan, serta ketakwaan yang mendalam yang harus muncul dalam sikap orang kaya. Tidak etis sebagai seorang makhluk sosial mau hidup sendiri tanpa memperhatikan kesulitan orang lain. Meskipun kejahatan sering merajalela di muka bumi, namun sejalan dengan itu sifat dan rasa belas kasihan dan tolong-menolong pun sudah menjadi budaya sejak adanya manusia dan tidak akan pernah hilang. Justru itulah kemudian zakat merupakan suatu kewajiban yang abadi, yang sudah disyariatkan pula atas umat-umat sebelum Islam.

Untuk memahami hakikat dan esensi zakat secara rasional dan logis tidaklah mudah, karena dalam syariat zakat ini terkandung suatu nilai sakral dan bahkan nilai ekonomik, yang agak sulit dipahami oleh orang awam apalagi untuk diamalkan. ${ }^{56}$

\footnotetext{
${ }^{54}$ Abdullah bin Muhammad bin Ahmad al-Thayyar, Al-Zakah wa Tathbigatuhu al-Muashirah, (Riyadh: Dâr al Wathan, 1414 H), h. 36.

${ }^{55}$ Lihat Abdurahman Qadir, Zakat dalam Dimensi Mahdhah dan Sosial, (Jakarta: PT Raja Grafindo Persada, 2001), h. 54-55.

${ }^{56}$ Ibid. h. 56.
} 
Secara filosofis realitas diposisikanya manusia menjadi dua golongan oleh Tuhan, yaitu kaya dan miskin, harus dipahami sebagai kerangka rencana Tuhan dalam menciptakan keseimbangan yang harmonis dan mewujudkan keadilan yang hakiki serta mendidik manusia supaya menghayati dan menerapkan sikap dan perilaku yang berkeadilan. Allah menetapkan sunnah-Nya dalam suatu kelebihan dan serba kekurangan. Sekiranya Allah samakan saja posisi dalam penerimaan rizki, seperti sama-sama kaya atau sama-sama miskin, maka hukum tidak diperlukan. Dengan kata lain, hukum tidak ada dan jika tidak ada hukum, kehancuran akan terjadi, karena masingmasing orang akan berbuat atau berperilaku semaunya sendiri menurut yang terbaik baginya. Akibatnya akan terjadi berbagai benturan yang bermuara kepada pemusnahan (hukum rimba). ${ }^{57}$

\section{Kesimpulan}

Dalam ensiklopedi al-Quran disebutkan, zakat dalam perspektif fiqih adalah upaya mengeluarkan sebagian harta, diberikan kepada yang berhak menerimanya, supaya harta yang tinggal menjadi bersih dan orang-orang yang memperoleh harta menjadi suci jiwa dan tingkah lakunya. Sedangkan secara teknis zakat dimaknai sebagai : "The tehnical meaning of the word designates the annual amount in kind or coint which a Muslim with means must distribut among the rightfull beneficiaries". Secara tehnis zakat adalah kewajiban seorang muslim mendistribusikan secara benar dan bermanfaat, sejumlah uang atau barang kepada yang berhak.

Berzakat adalah kewajiban syar'i yang harus ditunaikan sebagai refleksi dan realisasi dari rasa keadilan yang bersumber dari naqal dan akal sehat yang menurut konsep teologi golongan rasional seperti Mu'tazilah, bahwa akal sendiri sudah mampu menetapkan perbuatan yang baik dan buruk. Justru itu orang yang sadar dengan kewajiban membayar zakat digolongkan pada orang baik, pemurah dan berkeadilan. Sedangkan orang yang tidak mau membayarkan zakat digolongkan pada sikap bakhil, tidak manusiawi serta tidak berkeadilan. Dalam hal ini rasa keadilan dan berbuat adil adalah inti dari sebuah kebaikan.

\section{${ }^{57}$ Ibid.}




\section{Daftar Pustaka}

Al-Thayyar, Abdullah bin Muhammad bin Ahmad, Al-Zakah wa Tathbigatuhu al-Muashirah, Riyadh: Dâr al Wathan, 1414 H.

Qadir, Abdurahman, Zakat dalam Dimensi Mahdhah dan Sosial, Jakarta: PT Raja Grafindo Persada, 2001.

al-Wāhidy, Ab̄̄ al-Hasan, Asbāb al-Nuzūl, Mesir: Mustāfa al-Bāby alHālaby, 1968.

al-Banna, Ahmad bin Abdurahman, Fathu al-Rabbani Musnad Ahmad bin Hanbal, Cet. I, Cairo, al-Babi al-Halabi, $1370 \mathrm{H}$.

Al-Asfahani, Al-Mufradât fĩ Qarĩbi al-Qur'an, Beirut: Dâr al-Ma'ârif, tt.

Al-Bani, Mukhtashar Shahihul Bukhari, Cet. I, Beirut, Maktabah alMushannaf Abdurazlami, $1399 \mathrm{H}$.

Al-Bani, MukhtasharShahihul Bukhâri, dalam Hadits Encylopedia, [CD ROM], Lidya Pustaka i-Sowtware, 2010, hadits no. 7.

Al-Qardhawi, Musykilat al-Faqr wa kaifa 'alajaha al-Islam, Cet. II; Cairo: 1975 Maktabat Wahbah, 1975,

Departemen Agama RI, Al-Qur'an dan Terjemahnya, Surabaya: CV. Jaya Sakti, 1989.

Hafidhuddin, Didin, Panduan Praktis tentang Zakat, Infak, Sedekah, Jakarta: Gema Insani Press, 1998.

Fahruddin. HS., Ensiklopedi al-Quran, (Jakarta: Renika Cipta, 1992).

Abdalati, Hammudah, Islam in Focus, Indiana: American Trust Publication, 1980.

al-Țābary, Ibnu Jarir, Jāmi' al-Bayā 'an Ta'wīl al-Quran III, Beirut: Dār al-Fikr, 1998.

Anis, Ibrāhim, dkk., Mu'jām al-Wāsiţ I, Mesir: Dār al-Ma'ārif, 1972.

Ibn Mundzir, al-Fādhil Jāmal al-Dīn Muhammad ibn Mukrim, Lisān al-Arāb, Jilid I, Beirut: Dār Shādar, tt..

al-Baqi, Muhammad Fuad Abd, Al-Mu'jam Al-Mufahras Li Alfaz alQur'an, pada kata "zakat"

al-Anshāri, Muhammad Zakaria, Fathul Wahāb, Beirut: Dār al-Fikr, tt.

Binti Marzuki, Norhaziah Binti Nawai dan Ainulashikin, "The Role of Zakat in Developing Muslim Economy”, dalam Nik Salida Sulaiha Nik Saleh (Ed.), 2007, The Developmet of Economics and Muammalat Practices, Bandar Baru Nilai, Universiti Sains Islam Malaysia (USIM), 2007.

Shihab, M. Quraish, Tafsir al-Misbah, Cet. III, Jakarta: Lentera hati, 2005.

Shihab, M. Quraish, TafsirAmanah, Jakarta: Pustaka Kartini, 1992. 
Qutub, Sayyid, Fi-Zhilali al-Qur'an ,Kairo: Dâr al-Syuruq, 1982.

Sabiq, Sayyid, Fikh al-Sunnah, jilid III, Kuwait: Dâr al-Bayân, 1998. al-Nawāwi, Syaikh Muhammad, al-Majmū', Jilid 5, Beirut: Dār alFikr, tt.

Al-Husaini, Taqiyyuddīn Abū Bakar, Kifāyatul Akhyār, Juz I, Semarang: Usaha Keluarga, tt..

https:/ uinsgd.ac.id/ berita/ pentingnya-fiqh-zakat/

al-Zuhāily, Wahbah, al-Fiqh al-Islāmi wa 'Adilātuhu III, Beirut: Dār al-Fikr, tt.. 